\title{
Growth Hormone Gene Polymorphism and Its Association with Partial Cumulative Milk Yields of Holstein Friesian Dairy Cattle
}

\author{
R. Misrianti ${ }^{\mathrm{a}, *}$, A. Anggraeni ${ }^{\mathrm{b}}$, E. Andreas $^{\mathrm{c}}$, \& C. Sumantri $^{\mathrm{c}}$ \\ ${ }^{a}$ Faculty of Agriculture and Animal Science, Islamic State University SUSKA Riau, Indonesia \\ Jln. H R Soebrantas, Km 15 Panam Pekanbaru 28293. \\ 'Indonesian Research Institute for Animal Production \\ Jln. Veteran III, Desa Banjarwaru, Ciawi - Bogor 16002, Indonesia \\ 'Department of Animal Production and Technology, Faculty of Animal Science, Bogor Agricultural University \\ Jln. Agatis Kampus IPB Darmaga, Bogor 16680, Indonesia \\ (Received 28-10-2011; Reviewed 10-01-2012; Accepted 18-10-2012)
}

\begin{abstract}
Growth hormone gene (GH gene) plays an important role in regulating body growth and in developing mammary gland, similar with its interaction to specific receptors. The GH gene has been considered as one of candidate gene associated with selection on lactation trait and milk production. This study was aimed to determine genetic polymorphism of the GH-AluI gene and to associate its genotype variants on various 15-d partial cumulative milk yields in Holstein Friesian (HF) dairy cows. A number of 370 blood samples were collected from six HF populations, respectively from small dairy farmer under the supervision of the North Bandung Milk Cooperation (NBMC) in Cilumber (98) and Pasir Kemis village (96), Dairy Cattle Breeding and Improvement Station (Cikole DCBIS) Cikole (88), Lembang Artificial Insemination Center (Lembang AIC) (17), Singosari Artificial Insemination Center (Singosari AIC (32), and Cipelang Livestock Embryo Center (Cipelang LEC) (40). A polymerase chain reaction - restriction fragment length polymorphism (PCR-RFLP) method was used to identify variant genotypes of the GH gene using $A l u \mathrm{I}$ restriction enzyme. Genotyping results produced only two genotypes, i.e. LL and LV genotypes, without VV genotype. Frequency of the former was dominant, whilst that was low for the latter $(89 \%$ vs. $11 \%)$; leading to the frequency of $\mathrm{L}$ allele was very high $(94 \%)$ compared to that of $\mathrm{V}$ allele $(6 \%)$. No significant association between variant genotypes (LL and LV) and various 15-d partial cumulative milk yields.
\end{abstract}

Key words: growth hormone gene, milk yield, Holstein Friesian

\section{ABSTRAK}

Gen hormon pertumbuhan (gen growth hormone atau GH) berperan penting dalam mengatur proses pertumbuhan dan perkembangan kelenjar mammae, serta dalam interaksinya terhadap reseptor spesifik. Gen GH telah dipertimbangkan sebagai gen kandidat dari kegiatan seleksi sifat laktasi dan produksi susu. Studi ini bertujuan untuk mempelajari polimorfisme gen GH-AluI dan asosiasi keragaman genotipe-nya terhadap produksi susu kumulatif parsial pada setiap interval 15 hari dari sapi perah Friesian Holstein (FH). Sejumlah 370 sampel darah dikoleksi dari enam populasi sapi FH, berurutan meliputi peternakan sapi perah binaan Koperasi Susu Bandung Utara (KPSBU) di Pasir Kemis (96 sampel) dan Cilumber (98 sampel), Balai Pengembangan dan Pembibitan Sapi Perah (BPPT-SP) Cikole (88 sampel), BIB Lembang (17 sampel), BET Cipelang (40 sampel), dan BBIB Singosari (32 sampel). Polymerase chain reactions - restriction fragment length polymorphism (PCRRFLP) digunakan untuk mengidentifikasi keragaman genotipe dari gen $\mathrm{GH}$, menggunakan enzim restriksi $A l u I$. Hasil genotyping menghasilkan hanya dua tipe genotipe, yaitu genotipe LL dan LV, tanpa genotipe VV. Frekuensi genotipe LL adalah dominan $(89 \%)$, sebaliknya frekuensi genotipe LV rendah (11\%), sehingga diperoleh frekuensi alel L sangat tinggi (94\%), sebaliknya rendah untuk alel V (6 \%). Tidak ditemukan adanya hubungan yang nyata antara keragaman genotipe (LL dan LV) dengan produksi susu kumulatif parsial.

Kata kunci: gen hormon pertumbuhan, produksi susu, Friesian Holstein

\footnotetext{
*Corresponding author:
}

E-mail: rest_42@yahoo.co.id 


\section{INTRODUCTION}

Indonesian dairy cattle population is currently around 597,129 heads (DGLAH, 2011). Almost all of those dairy cattle, as producers of fresh milk in the country, are Holstein Friesian (HF) of Bos taurus dairy cattle. Raising dairy cattle is mostly concentrated in Java Island. Therefore, the highest volumes of producing fresh milk are from East Java, Central Java and West Java, for respectively 268,042; 100,350; and 536,458 tons. However, the capacity of milk production of dairy cattle should be increased, as the milking ability of HF dairy cows has just met around 35\% of the national milk demand. Attempts to make genetic improvement will increase milk yield of dairy cattle permanently, because genetic superiority of milk production will be passed from parent to offspring. One effort that can be done to improve genetic ability of HF cows in producing high milk yield is through a selection method.

Selection is commonly done by selecting superior bulls and cows to be used as sources of genetic material for the next generation. Selection in dairy cows is mainly based on the level of milk production. Milk production is a quantitative trait controlled by many genes and its expression is the accumulation of the factors of genetic, environment, and their interaction. Curently selection can be assisted by using molecular techniques. Selection based on genetic markers for a particular trait makes selection occuring early. Application of the genetic markers into livestock breeding programs can accelerate genetic improvement in livestock.

The GH gene has an important role in growth and development of postnatal longitudinal, growth of mammae and reproduction tissues, as well as metabolisms of protein, lipid, carbohydrate (Akers, 2006). Effects of the $\mathrm{GH}$ gene on the growth are observed in several tissues, including bone, muscle, and adiposa. In ruminants, the $\mathrm{GH}$ gene contributes to the development of udder glands (Akers, 2006). Growth hormone is an anabolic hormone that is synthesized and secreted by the anterior lobe cells in pituitary somatotrop. In bovine, the $\mathrm{GH}$ gene is located on chromosome 19 with a length of about $280 \mathrm{bp}$, composed by 5 exons and 4 introns. The GH protein consists of 191 amino acids with a molecular weight of $2 \mathrm{kDa}$ (Ayuk \& Sheppard, 2006).

The GH gene has been used as a genetic marker for the growth traits in some species such as cattle (Zhou et al., 2005; Jakaria et al., 2007 and Katoh et al., 2008), sheep (Marques et al., 2006), and goats (Boutinaud et al., 2003). Growth hormone (GH), growth hormone receptor (GHR) and other hormones such as Insulin-Like Growth Factor 1 (IGF1) are widely used as candidate genes of production traits in livestock and subsequently used as a genetic marker for selection. This is because these hormones are regulators of growth and development of the body (Zakizadeh et al., 2006). Studies on genetic polymorphism of the $\mathrm{GH}$ gene and its relationship to milk production in dairy cattle have been observed in Hungary Holstein Friesian (Balogh et al., 2009), Iranian Holstein (Mohammadabadi et al., 2010), and Poland Holstein Friesian (Olenski et al., 2010). Based on the results of those several studies it was known that the GH gene together with the GHR gene play an important role in regulating the growth of mammary gland and milk production, metabolism, lactation, and body composition (Kovács et al., 2006). This research had specific purposes to identify genetic polymorphism of the GH-AluI gene and to association variant genotypes of this gene to various 15-d milk yields in Holstein Friesian (HF) cattle.

\section{MATERIALS AND METHODS}

\section{Animals and Milk Yields}

Blood samples were collected from HF cattle, male and female, taken from the vena jugularis. A total number of $370 \mathrm{HF}$ blood samples were taken from six populations with different management or condition. Blood samples from HF heifers and cows were collected from Cikole Dairy Cattle Breeding and Improvement Station (Cikole DCBIS) located in Lembang, West Java for 88 samples, Cipelang Livestock Embryo Center (Cipelang LEC) for 34 samples, and from North Bandung Milk Cooperation Unit (NBMCU) at small farmers in the two villages of Cilumber (Cilumber NBMCU) for 98 samples and Pasir Kemis (Pasir Kemis NBMCU) for 95 samples. Blood samples from active and non active AI services of HF bulls from Lembang Artificial Insemination Center (Lembang AIC) for 17 samples and Singosari Artificial Insemination Center (Singosari AIC) for 32 samples. The collection of blood samples from these HF bulls was intended to know their genetic potency in transmitting the GH genetic polimorphism to HF cows.

Data of milk yields were collected from $56 \mathrm{HF}$ cows that were genotyped their the GH gene from Cikole DCBIS for production periods of 2008-2010. Data of milk yileds were in the range of I-4 lactation periods. Data of daily milk yields that were recorded weekly were estimated for various partially cumulative milk yields at each 15 -d intervals, since the $1^{\text {st }}$ until the $12^{\text {th }}$ partial cummulative milk yields $(15,30,45,60,75,90,105,120$, $135,150,165$, and $180 \mathrm{~d})$.

\section{Primer}

Primers used to amplify mutant locus of the GH I AluI gene followed Balogh et al. (2009), with a forward primer 5'-CGGACCGTGTCTATGAGAAGCTGAAG-3' and a reverse primer 5'-GTTCTTGAGCAGCGCGTCGTCA-3'. The amplified product or amplicon had the length of 432 bp.

\section{DNA Sample}

DNA samples obtained were from blood and semen. Blood samples used as DNA sources were 353 samples originating from 5 locations, while semen samples as DNA sources were 17 samples from Lembang AIC.

\section{DNA Extraction}

DNAs was extracted from blood and semen. Extraction procedure followed the phenol-chloroform 
method that was modified by Andreas et al. (2010), with the following procedures:

Sample preparation. Semen sample was added by alcohol $400 \mu$ l, whereas blood sample was added by alcohol $200 \mu \mathrm{l}$, then inserted into a $1.5 \mathrm{ml}$ tube. Alcohol was then eliminated from the sample by adding distilled water until $1000 \mu \mathrm{l}$, and left in room temperature for $20 \mathrm{~min}$. Then it was precipitated by centrifugation at a speed of 8000 rpm for $5 \mathrm{~min}$.

Protein degradation. Sample was cleared from alcohol by adding $200 \mu \mathrm{l} 1 x$ STE (sodium tris EDTA), $40 \mu \mathrm{l}$ sodium dosesil sulfate $10 \%$, and $20 \mu$ proteinase $\mathrm{K}(5 \mathrm{mg} /$ $\mathrm{ml})$. The mixture was incubated overnight at $55^{\circ} \mathrm{C}$ temperature.

Organic material degradation. After incubating, sample was added by $400 \mu \mathrm{l}$ phenol solution, $400 \mu \mathrm{l}$ choloform: isoamyl alcohol (24:1), and $40 \mu \mathrm{l} 5 \mathrm{M} \mathrm{NaCl}$. Then, the mixture was shaken at room temperature for one hour.

DNA precipitation. Samples was centrifuged at a speed of $5000 \mathrm{rpm}$ for $10 \mathrm{~min}$ to separate water phase over phenol phase. The water phase was transferred in a new tube with the volume measured. DNA molecules were deposited by adding a $2 x$ volume of alcohol absolute and $0.1 \mathrm{x}$ volume of $5 \mathrm{M} \mathrm{NaCl}$. Then the mixture was incubated at a temperature $-20{ }^{\circ} \mathrm{C}$ during the night. Subsequent DNA precipitation was centrifugated at a speed of $12000 \mathrm{rpm}$ for 10 minutes. The obtained DNA precipitation was washed by $70 \%$ alcohol, then reprecipitated. The precipitated DNAs was cleaned from alcohol by adding $100 \mu \mathrm{l}$ TE (Tris EDTA). The DNA samples were then stored at $-20{ }^{\circ} \mathrm{C}$ and ready for use.

\section{Amplification of the GH Gene}

Amplification of fragments of the $\mathrm{GH}$ gene was done by using PCR (polymerase chain reaction) method. Reagents used for the amplification of the targetted fragment were a $2 \mu \mathrm{l}$ sample DNA, each primer 25 pmol, $200 \mu \mathrm{M}$ dNTPs mixture, $1 \mathrm{mM} \mathrm{MgCl2}$, and 0.5 units of DreamTaq ${ }^{\mathrm{TM}}$ DNA Polymerase and 1x buffer (Fermentas) in total solution $25 \mu$ l. Amplification was by in vitro within GeneAmp® PCR System 9700 (Applied Biosystems $^{\mathrm{TM}}$ ). It was done with the condition of pradenaturation at $94{ }^{\circ} \mathrm{C}$ for $5 \mathrm{~min}, 35$ cycles consisting of denaturation at $94{ }^{\circ} \mathrm{C}$ for $45 \mathrm{~s}$, annealing primers at 62 ${ }^{\circ} \mathrm{C}$ for $45 \mathrm{~s}$ and extention of new DNA at $72{ }^{\circ} \mathrm{C}$ for $1 \mathrm{~min}$, and the final extention at $72{ }^{\circ} \mathrm{C}$ for $5 \mathrm{~min}$.

\section{Genotyping by RFLP Method}

Determination of genotypes of each individual cattle was done by using restriction fragment length polymorphism (RFLP) using AluI enzyme as a restriction enzyme. Visualization was conducted on $2 \%$ agarose gel with $0.5 \times$ TBE buffer (tris borate EDTA) at $100 \mathrm{~V}$ for 40 min. Gel was stained with an ethidium bromide, and visualized in UV transuliminator, alpha innotech alpha imager.

\section{Data Analysis}

Genotype frequency represents the ratio of a genotype to total population. Allele frequency is a ratio of an allele to the overall allele at a locus in the population. Mathematic models for genotype and allele frequencies (Nei \& Kumar, 2000) were as follows:

$$
\begin{aligned}
& x_{i i}=\left(n_{i i} / N\right) \times 100 \% \\
& x_{i}=\left(2 n_{i i}+n_{i j}\right) / 2 N \\
& \mathrm{x}_{\mathrm{ii}}=\mathrm{ii}^{\text {th }} \text { genotype frequency } \\
& \mathrm{x}_{\mathrm{i}}=\mathrm{i}^{\text {th }} \text { allele frequency } \\
& \mathrm{n}_{\mathrm{ii}}=\text { number of individual with ii genotype } \\
& \mathrm{n}_{\mathrm{ij}}=\text { number of individual with ij genotype } \\
& \mathrm{N}=\text { total number of individuals }
\end{aligned}
$$$$
\text { Degree of heterozigosity both observed }\left(h_{\mathrm{o}}\right) \text { and }
$$
expected $\left(h_{e}\right)$ were calculated with formula as follows:

$$
\begin{aligned}
& h_{o}=1-x_{i}^{2} \\
& h_{e}=2 n\left(1-\sum x_{i}^{2}\right) /(2 n-1) \\
& h_{o}=\text { observation heterozigosity } \\
& h_{e}=\text { expected heterozigosity } \\
& x_{i}=\mathrm{i}^{\text {th }} \text { allele frequency } \\
& n=\text { total number of individuals }
\end{aligned}
$$

For study of the associations was analyzed by the General Linear Model (GLM) with one factor. Parameter observed was various partially 15-d cumulative milk yields from 56 heads of the genotyped HF cows from the Cikole DCBIS. Mathematic model (Matjik \& Sumertajaya, 2006) was represented as follows:

$$
\begin{aligned}
& \gamma_{\mathrm{ij}}=\mu+\alpha_{\mathrm{i}}+\varepsilon_{\mathrm{ij}} \\
& \gamma_{\mathrm{ij}}=\text { a certain partial cumulative milk yield } \\
& \mu=\text { average } \\
& \alpha_{\mathrm{i}}=\text { additive effect from } \mathrm{i}^{\text {th }} \text { genotype } \\
& \varepsilon_{\mathrm{ij}}=\text { observed error }
\end{aligned}
$$

\section{RESULTS AND DISCUSSION}

\section{Amplification of the Growth Hormone Gene}

The amplified fragments were visualized on a $1.5 \%$ agarose gel (Figure 1). The amplified product (amplicon) of the GH gene had a fragment length of $432 \mathrm{bp}$, including $55 \mathrm{bp}$ of $4^{\text {th }}$ exon, $4^{\text {th }}$ intron and $99 \mathrm{bp}$ of $5^{\text {th }}$ exon (Balogh et al., 2009). One of key factor in determining the success of amplification is annealing temperature. Annelaling temperature is a temperature allowing the primers attaching on DNA templates during a PCR process. The annealing temperature $60{ }^{\circ} \mathrm{C}$ for $1 \mathrm{~min}$ in this study was accordance with those of some previous studies (Balog et al., 2009; Mohammadabadi et al., 2010, and Andreas et al., 2010).

\section{Identification of the GH Gene Polymorphism}

The $A l u \mathrm{I}$ enzyme as a restriction enzyme cut the recoqnized site of $\mathrm{ACIGT}$ bases. There are three AluI restriction sites that produce fragment lengths of 20,51, 


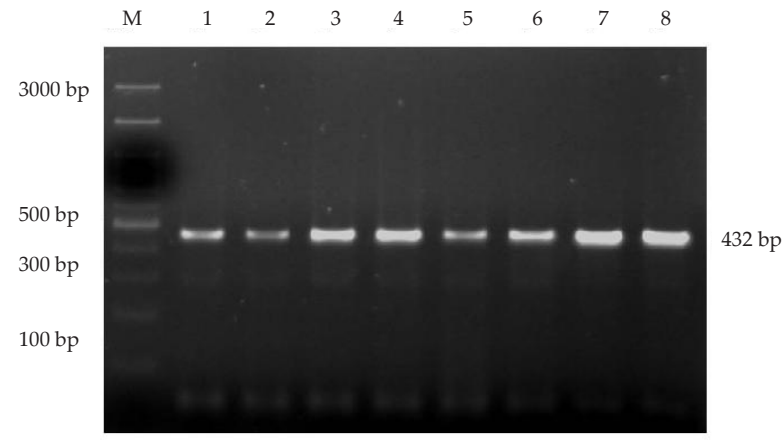

Figure 1. Visualization of the amplified GH gene fragment on $1.5 \%$ agarose gel. $\mathrm{M}=$ Marker 100 base pairs (bp), $1-8=$ number of sample.

96 and 265 bp, known as leucine (L) allele, and fragment lengths of 20, 147, and $265 \mathrm{bp}$, known as valine (V) allele. Genetic variation between $\mathrm{L}$ and $\mathrm{V}$ alleles was due to mutation at 1758 base resulting the changing base from $C$ to $G$ (Figure 2). A homozygous LL genotype is identified for having four fragment lengths of 20, 51, 96 , and $265 \mathrm{bp}$. A homozygous VV genotype is with the fragment lengths of 20,147, and $265 \mathrm{bp}$. A heterozygous LV genotype is then identified by fragment lengths of 20, 51, 96, 147, and 265 bp (Balogh et al., 2009).

Genotyping the $\mathrm{GH} \mid A l u \mathrm{I}$ gene resulted two genotypes, i.e. LL and LV (Figure 3). VV genotype was not found for all samples observed. Visualization of the genotypes of the GHIAluI gene was presented in Figure 3 . These results were in line with the study by Pereira et al. (2005) by obtaining two genotypes (LL and LV) in Brazilian Canchim cattle. Another study by Curi et al. (2006) did not find the VV genotype in Brazilian Zebu cattle and its crosses. However, the results of current study were not similar to that study by Dybus et al. (2002) that identified LL, LV, and VV genotypes of the $\mathrm{GH} \mid A l u \mathrm{I}$ gene in Polish Black and White cattle. The differences could be caused by breed of cattle, breeding system, and samples genotyped.

\section{Genetic Diversity of GH $\mid A l u I$ Gene within Holstein Friesian}

Frequencies of genotypes and alleles of the $\mathrm{GH} \mid$ AluI gene from all of HF cattle observed were presented in Table 1. Genotyping results on the GH|AluI gene showed that frequencies of the $\mathrm{L}$ allele were higher than those of the $\mathrm{V}$ allele. Frequencies of the L allele of HF cattle observed from all locations ranged from 0.92 to 0.98 . Higher frequencies of the $\mathrm{L}$ allele in the observed HF cattle resulted higher frequencies of the LL genotype contrasted to those for the LV genotype. No existence of the VV genotype in all of HF cows observed both in breeding station and small farmers could be influenced by $\mathrm{HF}$ bulls used for AI services. All of active AI-HF bulls came from the two national AICs (Lembang AIC and Singosari AIC). Genotyping of all HF bulls from both AICs proved that no bull having the VV genotype, whereas the $\mathrm{V}$ allele frequencies of those HF bulls were low.

The results from this studi corresponded with the study by Sorensen et al. (2002) by obtaining the higher

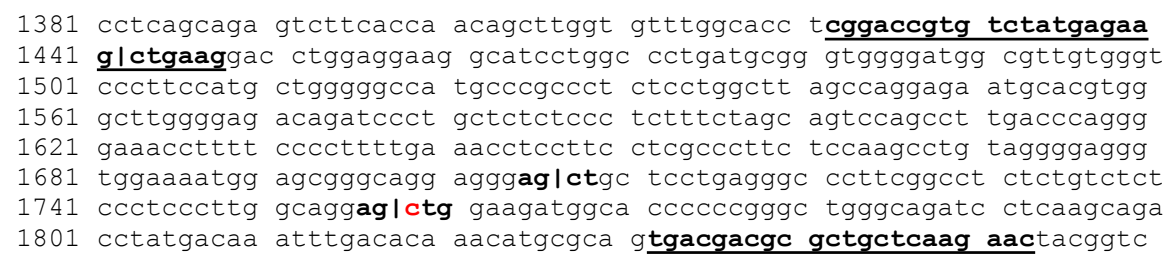

Figure 2. Nucleotide of the GHI AluI gene (Genbank access number J00008). Primary position (bold underlined), AluI enzyme cutting sites (bold), and point mutations (bold red) (Balogh et al., 2009).

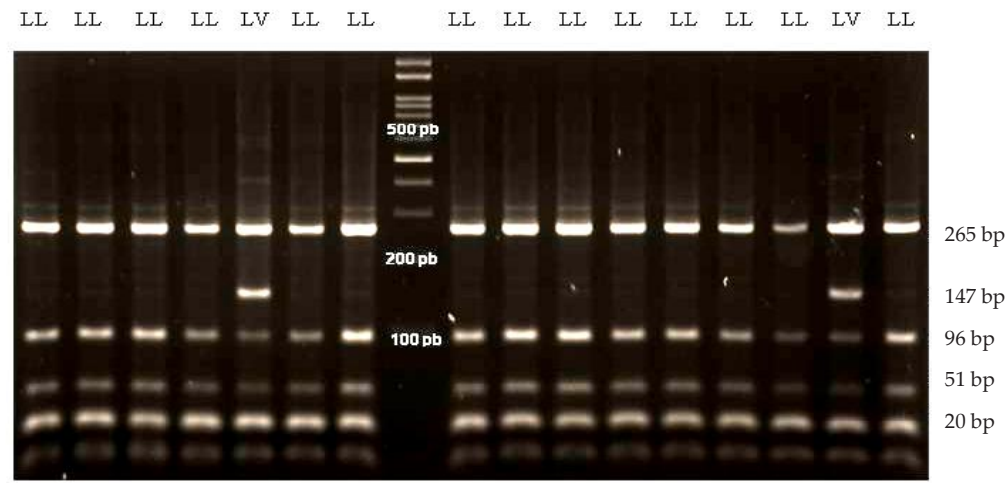

Figure 3. Visualization of the PCR-RFLP GHI AluI gene on 2\% agarose gel. M: Marker $100 \mathrm{bp}$. 
Table 1. Frequency of genotypes and alleles of the GHIAluI gene

\begin{tabular}{|c|c|c|c|c|c|c|}
\hline \multirow{2}{*}{ Population } & \multirow{2}{*}{$\mathrm{n}$} & \multicolumn{2}{|c|}{ Alel } & \multicolumn{3}{|c|}{ Genotipe } \\
\hline & & $\mathrm{L}$ & $\mathrm{V}$ & LL & $\mathrm{LV}$ & VV \\
\hline Singosari AIC & 32 & 0.92 & 0.08 & $0.84(27)$ & $0.16(5)$ & 0.00 \\
\hline Lembang AIC & 17 & 0.97 & 0.03 & $0.94(16)$ & $0.06(1)$ & 0.00 \\
\hline Cikole DCBIS & 88 & 0.94 & 0.06 & $0.88(77)$ & $0.13(11)$ & 0.00 \\
\hline Cilumber NBMCU & 98 & 0.93 & 0.07 & $0.86(84)$ & $0.14(14)$ & 0.00 \\
\hline Pasir Kemis NBMCU & 95 & 0.96 & 0.04 & $0.92(87)$ & $0.08(8)$ & 0.00 \\
\hline Cipelang LEC & 40 & 0.98 & 0.02 & $0.95(38)$ & $0.05(2)$ & 0.00 \\
\hline Total & 370 & 0.94 & 0.06 & $0.89(323)$ & $0.11(47)$ & 0.00 \\
\hline
\end{tabular}

Note: $\mathrm{L}=$ leusine, $\mathrm{V}=$ valine.

frequenci of the LL genotype $(0.85 \%)$ than that of the LV genotype $(0.15 \%)$ of the GHIAluI gene in Danish Holstein cattle. The results of this study, however, contrasted with the study by Grochowska et al. (2001) in Polish Friesian cattle that reported LL, LV, and VV genotypes, with the highest frequency for the LL genotype (51\%) and the lowest for the VV genotype (13\%). Another study by Sabour et al. (1997) in Ayrshire, Holstein and Jersey dairy cattle also identified LL, LV and VV genotypes, with the frequencies were 0.29, 0.09, and 0.24 respectively.

\section{Heterozigosity}

The degree of heterozigosity represents the mean percentage of heterozygous loci per individual or the mean percentage of heterozygous individuals in a population. Estimation of the heterozygosity degree is important to know genetic variability and to determine the level of polymorphism of alleles. High heterozygosity shows high genetic diversity within a population (Nei \& Kumar, 2000).

Predicted degree of heterogozity of the GHIAluI gene was presented in Table 2. heterozygosity of the $\mathrm{GH} \mid A l u \mathrm{I}$ gene ranged between 0.050-0.156. The highest heterozygosity was found in HF bulls from Singosari AIC, whilst the lowest one was found in HF cows from Cipelang LEC. By comparing the results of observed heterozygosity analysis $\left(\mathrm{H}_{\mathrm{o}}\right)$ and expected heterozygosity $(\mathrm{He})$ at $\mathrm{GH} \mid \mathrm{AluI}$ gene indicated no statistically difference (Table 2). Tambasco et al. (2003) stated that if the value of observed heterozygosity $\left(\mathrm{H}_{\mathrm{o}}\right)$ is much lower compared to that value of expected heterozygosity $\left(\mathrm{H}_{\mathrm{e}}\right)$, it might indicate a more intense selection or a higher degree of inbreeding.

Based on the heterozygosity values obtained in the $\mathrm{GH} \mid A l u \mathrm{I}$ gene from all of HF cattle observed from all locations, it could be stated that the GHIAluI gene had a low degree of genetic diversity. Selection in livestock expects high heterozygosity, as the high heterozygosity reflects genetic variation of genes in a population. A higher value of heterozygosity of genes could give a greater opportunity for selection of genes in a population.

\section{Association between the GH Genotypes and Partial Cumulative Milk Yield}

Investigation of the association between variant genotypes of the $\mathrm{GH} \mid A l u \mathrm{I}$ gene on partial cumulative milk yields of HF cows was conducted at Cikole DCBIS in Lembang, West Java. Study on the effects of the LL and LV genotypes on various partially cumulative milk yields at each 15-d interval of HF cows were presented in Table 3 . The results generally seemed that the LV cows tended to have a higher milk production than those of the LL cows. These were really evident for cumulative milk yields around $135 \mathrm{~d}$ to $180 \mathrm{~d}$ of lactation. Statistical analysis however proved that those LL and LV genotypes the GHIAluI gene did not give significantly effects on all of partially cumulative milk yields observed. These results indicated that the examination on the GH gene solely did not provide sufficiently effect on milk production of HF cattle. This was because milk production is one of quantitative traits that are controlled by poly genes. Beside of that, milk production as a quantitative trait is also affected by other factors, both genetic and environment factors. Some environment factors could be possible in affecting dairy cattle milk yields, such as lactation periode (calving age), days open, days dry, calving season, and calving year (Anggraeni, 2012).

Table 2. Heterozigosity observed $(\mathrm{Ho})$ and heterozigosity expected $(\mathrm{He})$ on $\mathrm{GH} \mid \mathrm{AluI}$ gene

\begin{tabular}{lccc}
\hline \multirow{2}{*}{ Location } & \multirow{2}{c}{ GHIAluI } \\
\cline { 3 - 4 } & & Ho & He \\
\hline Lembang AIC & 17 & 0.059 & 0.057 \\
Singosari AIC & 32 & 0.156 & 0.144 \\
Cikole DCBIS & 88 & 0.125 & 0.117 \\
Cilumber NBMCU & 98 & 0.143 & 0.133 \\
Pasir Kemis NBMCU & 95 & 0.084 & 0.081 \\
Cipelang LEC & 40 & 0.050 & 0.049 \\
\hline
\end{tabular}

Note: $\mathrm{n}=$ sum of sample (head). 
Table 3. Associations between the GH gene polymorphism with partial cumulative milk yield (L)

\begin{tabular}{cccc}
\hline $\begin{array}{c}\text { Partial cu- } \\
\text { mulative milk } \\
\text { yield (d) }\end{array}$ & \multicolumn{2}{c}{ Genotype of the GHIAluI gene } & P \\
\cline { 2 - 3 } & $145.6 \pm 66.65$ & $147.4 \pm 103.7$ & 0.957 \\
15 & $316.0 \pm 136.0$ & $316.2 \pm 197.8$ & 0.998 \\
30 & $464.4 \pm 180.1$ & $484.0 \pm 272.0$ & 0.818 \\
45 & $598.9 \pm 216.7$ & $654.0 \pm 345.0$ & 0.603 \\
60 & $730.8 \pm 236.8$ & $823.0 \pm 392.0$ & 0.433 \\
75 & $861.8 \pm 264.0$ & $965.0 \pm 450.0$ & 0.435 \\
90 & $992.9 \pm 284.3$ & $1103.0 \pm 492.0$ & 0.442 \\
105 & $1118.0 \pm 316.0$ & $1249.0 \pm 508.0$ & 0.400 \\
120 & $1243.5 \pm 345.9$ & $1394.0 \pm 599.0$ & 0.273 \\
135 & $1366.0 \pm 360.6$ & $1542.0 \pm 599.0$ & 0.327 \\
150 & $1483.0 \pm 301.4$ & $1691.0 \pm 637.0$ & 0.284 \\
165 & $1585.0 \pm 406.3$ & $1815.0 \pm 659.0$ & 0.354 \\
180 & & &
\end{tabular}

Note: $\mathrm{L}=$ leusine, $\mathrm{V}=$ valine

Results of this study however differed from that reported by Grochowska et al. (2001) that identified the $\mathrm{GH} \mid \mathrm{AluI}$ gene significantly influenced on 305-d milk production. The LL cows were reported producing higher milk yield by $171.7 \mathrm{~kg}$ compared to those LV cows. It was also reported that the first cows producing fat content of $8.8 \%$ higher than the latter cows. Yardibi et al. (2009) also reported that the variant genotypes (LL, LV, and VV) of the GHIAluI gene had positive correlation with percentages of fat content and protein content of milk, but no correlation was found between those variant genotypes with milk production of dairy cattle. Investigation on some other breeds of dairy cattle proved that the LL genotype had higher milk production than the VV genotype (Dario et al., 2008; Sadeghi et al., 2008).

\section{CONCLUSION}

The GHIAluI gen of HF cattle from six populations observed in this study had only two genotypes, i.e. LL and LV genotypes and with two types of $\mathrm{L}$ and $\mathrm{V}$ alleles. Frequencies of the LL genotype were very high (0.88$0.94)$, whilst those ferquencies of the LV genotype were very low $(0.05$ to 0.16$)$. The values of both of observed heterozygosity $\left(\mathrm{H}_{\mathrm{o}}\right)$ and expected heterozygosity $\left(\mathrm{H}_{\mathrm{e}}\right)$ of the $\mathrm{GH} \mid A l u \mathrm{I}$ gene were not significantly different that could be an indication of a closer mating within population. No significant association between varian genotypes of the $\mathrm{GH} \mid A l u \mathrm{I}$ gene with partially cumulative milk yileds.

\section{REFERENCES}

Akers, R.M. 2006. Major advances associated with hormone and growth factor regulation of mammary growth and lactation in dairy cows. J. Dairy Sci. 89:1222-1234. http://dx.doi. org/10.3168/jds.S0022-0302(06)72191-9
Andreas, E., C. Sumantri, H. Nuraini, A. Farajallah, \& A. Anggraeni. 2010. Identification of GH|AluI and GHRIAluI Genes Polymorphisms in Indonesian Buffalo. J. Indon. Trop. Anim. Agric. 35:215-221.

Anggraeni, A. 2012. Perbaikan genetik sifat produksi susu dan kualitas susu sapi Friesian Holstein melalui seleksi. Wartazoa. 22: 1-11.

Ayuk, J. \& M. C. Sheppard. 2006. Growth hormone and its disorders. Postgrad Medic. J. 82: 24-30.

Balogh, O., K. Kovacs, M. Kulcsar, A. Gaspardy, H. Febel, A. Zsolnai, L. Fesus, C. Delavaud, Y. Chilliard, R. O. Gilbert, \& Gy. Huszenicza. 2009. Interrelationship of growth hormone AluI polymorphism and hyperketonemia with plasma hormones and metabolites in the beginning of lactation in dairy cows. Livestock Sci. 123:180-186. http:// dx.doi.org/10.1016/j.livsci.2008.11.002

Boutinaud, M., C. Rousseau, D. H. Keisler, \& H. Jammes. 2003. Growth hormone and milking frequency act differently in goat mammary gland in late lactation. J. Dairy Sci. 86:509520. http://dx.doi.org/10.3168/jds.S0022-0302(03)73629-7

Curi, R.A. 2006. Growth and carcass traits associated with $\mathrm{GH} \mid \mathrm{Alu} 1$ and POU1F1|HinfI gene polymorphism in Zebu and crossbred beef catle. Genet. Mol. Bio. 29: 56-61. http:// dx.doi.org/10.1590/S1415-47572006000100012

Dario, C., D. Carnicella, F. Ciotola, V. Peretti, \& G. Bufano. 2008. Polymorphism of growth homone GH1-AluI in Jersey cows and its effect on milk yield and composition. Asian-Aust. J. Anim. Sci. 21:1-5.

DGLAH (Directorat General Livestock and Animal Health). 2011. Livestock and Animal Health Statistic. Ministry of Agriculture, Republic of Indonesia, Jakarta.

Dybus, A. 2002. Association between leu/val polymorphism of growth hormone gene and milk production traits in Black and White cattle. Arch Tiers 45: 421-428.

Grochowska R., P. Sorensen, L. Zwierzchowski, M. Snochowski, \& P. J. Lovendahl. 2001. Genetic variation in stimulated GH release and in IGF-I of young dairy cattle and their associations with the leucine/valine polymorphism in the GH gene. J. Anim. Sci. 79: 470-476.

Jakaria, D. Duryadi, R. R. Noor, B. Tappa, \& H. Martojo. 2007. Evaluasi keragaman genetik hormone pertumbuhan (GH) pada sapi pesisir Sumatera Barat menggunakan penciri. Med. Pet. 30:1-10.

Katoh, K., S. Kouno, A. Okazaki, K. Suzuki, \& Y. Obara. 2008. Interaction of GH polymorphism with body weight and endocrine functions in Japanese black calves. Domest Anim. Endocrinol. 34: 25-30. http://dx.doi.org/10.1016/ j.domaniend.2006.10.003

Kovács K., J. Völgyi-Csík, A. Zsolnai, I. Györkös, \& L. Fésüs. 2006. Associations between the AluI polymorphism of growth hormone gene and production and reproduction traits in a Hungarian Holstein-Friesian bull dam population. Arch. Anim. Breed. 49: 236-249.

Mattjik, A. A. \& M. Sumertajaya. 2006. Perancangan Percobaan dengan Aplikasi SAS dan Minitab, Jilid 1. Bogor: IPB Press.

Marques, M. R., I. C. Santos, N. Carolino, C. C. Belo, R. Renaville, \& A. Cravador. 2006. Effects of genetic polymorphisms at the growth hormone gene on milk yield in Serra da Estrela sheep. J. Dairy Res. 73: 394-405. http://dx.doi. org/10.1017/S0022029906001932

Muhammadabadi, M. R., M. A. Torabi, M. Tahmoursesspor, A. Baghizadesh, A. K. Esmaillizaeh, \& A. Muhammadi. 2010. Analysis of bovine growth hormone gene polymorphism of local and Holstein cattle breeds in Kerman province of Iran using polymerase chain reaction restriction fragment length polymorphism (PCR-RFLP). Afric. J. Biotechnol. 9:6848-6852.

Nei, M. \& S. Kumar. 2000. Molecular Evolutionary Genetics. 
New York: Columbia University Press.

Olenski, K., T. Suchocki, \& S. Kamiński. 2010. Incosistency of association between growth hormone receptor gene polymorphism and milk performance traits in polish Hosltein-Friesian cows and bulls. Anim. Sci. Papers Reports. 28:229-234

Pereira, A. P., M. M. de Alencar, H. N. de Oliveira, \& L. C. de Regitano. 2005. Association of GH and IGF-1 polymorphisms with growth traits in a synthetic beef cattle breed. Gen. Mol. Biology 28: 23-30. http://dx.doi.org/10.1590/ S1415-47572005000200009

Sadeghi, M., M. M. Shahr-e-Babak, G. Rahimi, \& A. N. Javaremi. 2008. Association between gene polymorphism of bovine growth hormone and milk traits in the Iranian Holstein Bulls. Asian J. Anim. Sci. 2:1-6. http://dx.doi. org/10.3923/ajas.2008.1.6

Sabour, M. P., C. Y. Lin, \& C. Smtth. 1997. Association of genetic variants of bovine growth hormone with milk production traits in Holstein cattle. J. Anim. Breed. Gen. 114: 435-442. http://dx.doi.org/10.1111/j.1439-0388.1997.tb00529.x

Sorensen, P., R. Grochowska, L. Holm, M. Henryon, \& P. Løvendahl. 2002. Polymorphism in the Bovine Growth Hormone Gene Affects Endocrine Release in Dairy Calves. J. Dairy Sci. 85:1887-1893.
Tambasco, D. D., C. C. P. Paz, M. Tambasco-Studart, A. P. Pereira, M. M. Alencar, A. R. Freitas, L. L. Coutinho, I. U. Packer, \& L. C. A. Regitano. 2003. Candidates genes for growth traits in beef cattle crosses Bos taurus $\mathrm{x}$ Bos indicus. J. Anim. Breed. Genet. 120:51-60. http://dx.doi. org/10.1046/j.1439-0388.2003.00371.x

Yardibi, H., G. T. Hosturk, I. Paya, F. Kaygisiz, G. Ciftioglu, A. Mengi, \& K. Oztabak. 2009. Association of growth hormone gene polymorphisms with milk production traits in South Anatolian and East Anatolian Red Cattle. J. Anim. Vet. Advan. 8:1040-1044. http://dx.doi.org/10.3923/javaa.2009.1040.1044

Zakizadeh, S., G. Rahimi, S. R. Mirae-Ashtiani, A. Nejati-Javaremi, M. Moradi-Shahrbabak, P. Reinecke, M. Reissmann, A. A. Masoud, C. Amirinia, \& S. A. Mirhadi. 2006. Analysis of bovine growth hormone gene polymorphism in three Iranian native breeds and Holstein Cattle by PCRRFLP. J. Biotech 5:385-390. http://dx.doi.org/10.3923/biotech.2006.385.390

Zhou, G. L., H. G. Liu, C. Liu, S. L. Guo, Q. Zhu, \& Y. H. Wu. 2005. Association of genetic polymorphism in GH gene with milk production traits in Beijing Holstein cows. J. Biosciences 30: 595-598. http://dx.doi.org/10.1007/BF02703558 